\title{
ESKi BIR SOVYET ANIT HEYKELININ DÖNÜŞÜMÜ; LENIN DIED HEYKELI
}

\section{TRANSFORMATION OF AN OLD SOVIET MONUMENT SCULPTURE; LENIN DIED SCULPTURE}

\author{
Mert Taşkın Demir*
}

Öz

Sovyetler Birliğinin dağılmasının ardından bağımsızlığını ilan eden ülkelerde, eski sistemin propagandalarına dair kamusal alanlara yerleştirilen heykellerin tasfiyesine ya da imhasına dair uygulamalar başlamıştır. Bu anıtlardan bir tanesi Danimarkalı iş adamı ve koleksiyoner Aage Damgaard tarafından Letonya'dan satın alınarak Danimarka'ya getirilmiştir.

Bu çalışma, Otto Kalejs'e ait olan Lenin'e adanmış anıt heykelin, bir nesne olarak el değiştirmesi ve dönüşümü üzerine odaklanmıştır. Eser, Damgaard ailesinin isteğiyle başka bir sanatçı Sven Dalsgaard tarafından farklı bir uygulamaya eklemlendirilmiştir. Ortaya çıkan yeni eserin biçimsel ve politik mesajındaki dönüşüm makalenin inceleme konusudur.

Makalede, Sovyet anıtlarındaki iktidarı ve Devrimin mutlakıyetini işaret eden katı biçim diline kontrast olarak Sven'in kullandığı soyut organik biçimler ile yaratılan dengeli ama bir o kadar zıt yapının çözümlenmesi ve açığa çıkan yeni iletisinin yorumlanması hedeflenmiştir. Yeni kimliği ile ortaya çıkan Lenin Died heykeline dair eser çözümlemesi yapılmış ve ikonolojik açıdan yorumlanması yoluyla ele alınmıştır. Bir anıtın iletisinin nasıl tersine çevrildiği ve nasıl sivilleşebildiği görülmüş, anma kavramının kamuyla ilişkisi ortaya konmuştur.

Anahtar Kelimeler: Lenin Anıtı, Lenin Died, Otto Kalejs, Sven Dalsgaard, İroni.

\section{Abstract}

In the countries that have declared their independencies after Soviet Union's disintegration, implementations of liquidation and destruction of the sculptures that were located in public spaces for the purpose of old system propaganda has began. One of these monuments was purchased from Latvia and brought to Denmark by a Danish businessman and collector Aage Damgaard.

This work focuses on the transition and the transmission of ownership as an object of the monument that belongs to Otto Kalej and which is dedicated to Lenin. Art work has been adapted to a different implementation by another artist Sven Dalsgaard with the request of Damgaard family. The transmission in the formal and political message in the nascent new art work is the study subject of the article.

In the article, interpretation of the emerging new message and analyzation of the stable but as much opposite formation that is created by abstract organic shapes used by Sven in contrast to the sharp shape that signs the absolutism of the Revolution and power of the Soviet monuments has been targeted. Analyzation of the sculpture relating to the Lenin Died that appears with its new identity has been realized and it has been taken in hand in terms of iconologic Interpretation. The way how the message of a monument has been inverted and how it become civilian has been observed, citation concept relation with the public has been presented.

Keywords: Lenin Monument, Lenin Died, Otto Kalejs, Sven Dalsgaard, Irony.

Araştırma Makalesi // Başvuru tarihi:14.03.2020 - Kabul tarihi:16.06.2020.

*Araş. Gör., Mert Taşkın Demir, Dokuz Eylül Üniversitesi, Güzel Sanatlar Fakültesi, Heykel Bölümü, m.taskindemir@gmail.com, https://orcid.org/0000-0002-1575-5030. 


\section{Giriş}

Ekim devriminin ardından Lenin, devrimin kalııılığı adına farklı propaganda yöntemleri uygulamıştır. Öncelikle, devrimin yükselişini ve heyecanını yaymayı amaçlayan propagandist sözlü iletilere ardından ikinci aşamada da kamusal alanlarda sürekli dikteyi sağlayan plastik etkilere başvurmuştur. Rus devriminin mimarı olarak Lenin betimlemelerini kullandırmamıştır. Devrimin coşkusunu okuma yazma oranı çok düşük olan halkı manipüle etme amaçlı propagandalarla tarif ettirmiş ve toplumun gelişimi adına kamusal alanlardaki çarlık heykellerini kaldırtarak yerine önemli Rus düşünürlerinin heykellerini tercih etmiştir (Clark, 2017:94-108).

Yeni toplumsal düzenin ilk yıllarında sağlığını kaybeden ve hayal ettiklerini gerçekleştiremeden yönetimden çekilmek zorunda kalan Lenin, başa geçen Stalin tarafından sürekli Devrimin yüzü olarak kullanılmıştır. Tüm süreç boyunca ve günümüzde dahi, Sovyet Devrimi, sistemi diktatörlüğe taşıyan Stalin ile değil, Stalin'in propaganda nesnesi olarak kullandığı Lenin ile anılmıştır. Bu strateji nedeniyle Stalin'in bellekte kalan tüm despotluklarından Lenin sorumlu tutulmuştur. Oysaki Lenin, Devrim propagandasının kendi imgeleri üzerinden gerçekleştirilmesinde hep isteksizdir (Buck-Morss, 2004:84).

1989 yılındaki Sovyetler Birliği'nde yaşanan demokratik değişimlerin hemen ardından bu idealin (Sosyalist Rusya/Bolşevik Devrimi) yaratıcısı olan Lenin'e adanmış olan heykeller, Sovyetler Birliği'ne dâhil edilen ve bağımsızlığını ilan eden ülkelerde yerlerinden sökülerek imha edilmeye başlamıştır. Partizanları ve Sovyet ordusunu anan ve öven anıtlardan farklı olarak kamusal alanlardaki ilk Lenin betimlemelerinin tasfiyesi dikkat çekicidir. O zamana kadar pozitif bir toplumsal çıkar yol olarak kabul gören Leninizm'i dikte eden bu imgelerin göz önünden kaldırılması ile yaşanılan acılı sürecin hafızalardan silinmesi hedeflenmiştir. Halk eliyle gerçekleşen devrimin hayalleri (özgürlük, iyi-eşit bir yaşam hakkı) çok geçmeden despotlaşan sistem tarafından halkın elinden alındığından, yaratılan devrim gücünün altında neredeyse ezilen Sovyet toplumunun başlardaki heyecanı ve inancı öfkeyi barındıran bir kitle hissiyatına dönüşmüştür (Goldman, 2008:24-31).

Zamanında heyecan yaratan bir toplumsal sistemi tüm inancı ile kabul eden Sovyet halkının eskiye dair öfkesini heykellerden alıyor olmasını, heykel vandalizmi olarak tarif etmek 
mümkün olsa da toplumca yok edilmeye çalışılan Lenin imgesi, Lenin ile anılan devrimin büyük hayal kırıklığını ve ardından gelen zorlu bir sürecin hatıralarını/bilinçaltını kapsar. Lenin betimlemeleri, tüm süreçte o kadar çok kullanılmıştır ki hafızalara kaydedilen komünist sistemin kötü hatıralarının hesabının yine Lenin'den sorulması kabul edilebilir bir tepki olarak açığa çıkmaktadır. Artık bu anıtlar, birer sanat nesnesi olmaktan ziyade, artistik verileri göz ardı edilmiş ve kişiselleşmiş birer uyaran konumunda değerlendirilmektedir.

Dönemin anıtları taşıdıkları plastik değerler dikkate alınmadan, önce hurdalıklara ya da depolara kaldırılmış ardından tekrar kullanılmak üzere ergitilerek bronzu kullanılmış ve sonsuza kadar kaybolmuştur. Görsel propaganda amacı ile neredeyse her şehirde, her kasabada, her kurumda mevcut olan Lenin resimleri ve heykelleri tasfiye edilirken eserlerin bir kısmı da özel koleksiyonerler, galeriler ve bazı belediyeler tarafından koruma altına alınarak varlıklarını sürdürmüşlerdir. 1990 yılında Letonya Jelgava'da bulunduğu meydandan sökülerek depoya kaldırılan Lenin anıtlarından bir tanesi de Otto Kalejs'in heykelidir.

Bu çalışmada, Otto Kalejs'e ait olan Lenin'e adanmış anıt heykelin, Sovyetler birliğinin dağılmasının ardından bir nesne olarak el değiştirmesi ve ardından sanatçı Sven Dalsgaard tarafından bir başka uygulamanın parçası olarak kullanımı incelenmiştir.

Sovyetler birliğinin kurucusu Lenin'e atfedilmiş anıtların, sistemin yıkılışının ardından karşılaştıkları muameleye örnek olarak "Lenin Died" isimli heykel irdelenmiştir. Çalışmanın temelini oluşturan eser, ilk olmasa da heykel yapıtlarına dair gerçekleştirilen saldırılardan ya da imhalardan farklı olarak yeniden ortaya konuluşundaki müdahale hassasiyeti bakımından dikkat çekicidir ve bu nedenle örnek olarak tercih edilmiştir. Eser, kamusallığın ve kamusal alana olan aidiyetinin dönüşümü ile iyi bir örnek niteliği taşımaktadır. Yaratılmış Lenin imgesinin, bahsi geçen anıttaki dönüştürülüş yöntemi, anıtın artık neyi ifade ettiği ve nasıl bir sonuca ulaşıldığı incelenmiştir. Veri toplama aracı olarak; sanat eseri inceleme, literatür tarama yöntemlerinin kullanıldığı bu çalışmada eskiyi anlatan ve hatırlattıklarından dolayı rahatsızlık hissettiren bir yapıtın, yeni bir söylemle üstelik politik diktesinin de yeniden tarif edilebilmesi vurgulanmıştır.

Uygulamaya dair çözümleme, kompozisyon, heykelin konumlandırılması ve ikonolojik yorumlama kapsamında ayrı ayrı değerlendirilerek gerçekleştirilmiştir. Esere dair yapılan 


\section{SDÜ ART-E}

Güzel Sanatlar Fakültesi Sanat Dergisi

çözümlemeler sayesinde iki farklı tavırda/amaçta olan sanatçının yarattığı plastiğin yeni bir anlam ve algı ile varlık buluşu incelenmiş, elde edilen bulgulara da sonuç kısmında yer verilmiştir.

Yapılan literatür taraması esnasında söz konusu heykelin bu çalışmada geliştirilen bakış açısıyla daha önce irdelenmediği sonucuna varılmıştır. Bu sebepten, üzerinde çalışılan konu özgünlük taşımaktadır.

\section{Sovyetlerin Dağılmasının Ardından Lenin Anıtlarına Müdahaleler}

Doğu bloğu ülkelerinde, demokratik değişimlerle birlikte açığa çıkan Sovyet sembollerine karşı mücadele hareketi ile başlayan heykel imhasının yanında, heykellere mevcut yerlerinde müdahaleler veya ironik mekân değişiklikleri ilk değildir. İster sanatsal olsun ister öfkeli bir imha olsun, 1990 yılından sonra Lenin betimlemeleri üzerinde yapılan değişikliklerle yeni toplumsal sistemin dönüştüğünün vurgulanması hedeflenmiştir. Eski sisteme karşı en büyük tepkisel hareketlerin Ukrayna'dan açığa çıktığı söylenebilir. Gerek halk gerek hükümet cephesinde karşıt faaliyetler gözlemlenmiştir. Müdahaleler, genellikle yüzeysel (boyama vs.) ya da tüm kütlenin/biçiminin kontrolsüzce parçalanışı ile sınırlı kalmıştır.

Sosyalizme dair belleğin silinmesine yönelik müdahaleler Ukrayna hükümetinin, 2015 yılında yürürlüğe koyduğu "de-communization" yasaları ile anıt tasfiyesini resmi hale getirmiştir. Bu kararların bir sonucu olarak Hanna Bondar eserlerin tasfiyesi için Ukrayna Cumhurbaşkanı tarafından görevlendirilmiştir. Hanna Bondar'a göre kamusal alanlar tarihi kişilikleri sergileyen mekânlar değildir. O’na göre kamusal alanlar yaşayan insanlara hizmet etmesi gereken mekânlardır. Bahsi geçen kanun çerçevesindeki ilk projesi Kiev'deki Bessarabska Meydanı'nın tekrardan düzenlenmesi olmuştur. Daha evvel büyük bir Lenin heykelinin yer aldığı meydanın sivilleştirilmesi amacı ile tasarım yarışması düzenlemiştir. En sevdiği fikirlerden biri (Görsel 1), kaidenin boş bırakılması ve bir merdiven eklenmesidir. "Tırmanmak, etrafa bakmak ve bir anıt gibi hissetmek isteyen herkes için..." (Wollan, 2017:32). 
SDÜ ART-E

Güzel Sanatlar Fakültesi Sanat Dergisi

Haziran'20 Cilt:13 Sayı:25

ISSN 1308-2698

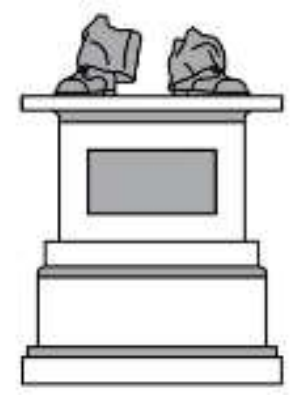

Görsel 1. Kiev'deki Bessarabska Meydanı'ndaki Lenin Anıtının Yerine Önerilen Proje.

Çalışmanın temelini oluşturan Lenin Died heykeli yukarıda bahsi geçen sıradan vandallık hareketlerinden veya yüzeysel artistik müdahalelerden farklı olarak biçimsel bir bozulmaeksiltme gerçekleşmeksizin yeniden üretimle tekrar varlık bulmuştur. Diğer girişimler ya eski etkisini azaltmaya yetemeyen zayıf kitsch müdahaleler boyutunda kalmış ya da mekân değişimleri yapılmış olsa da kamusal bir süreklilik arz eden tarife ulaşamamıştır (Görsel $2,3,4,5,6,7,8)$.

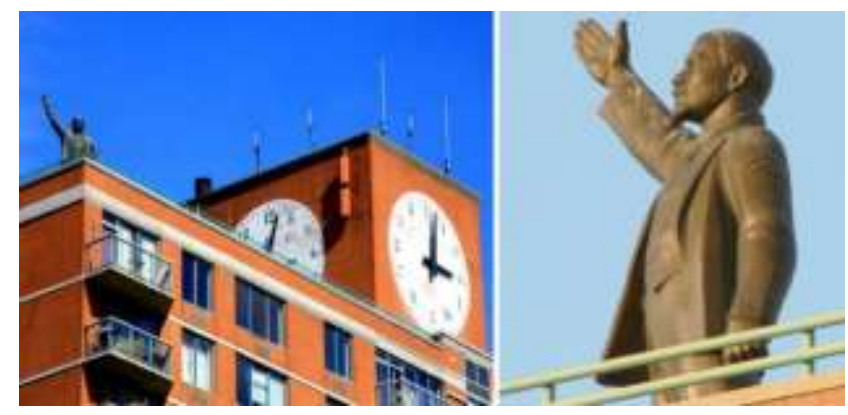

Görsel 2. Yuri Gerasimov, Lenin, 1990, Bronz, Red Square Apartmanı çatısı, Amerika.
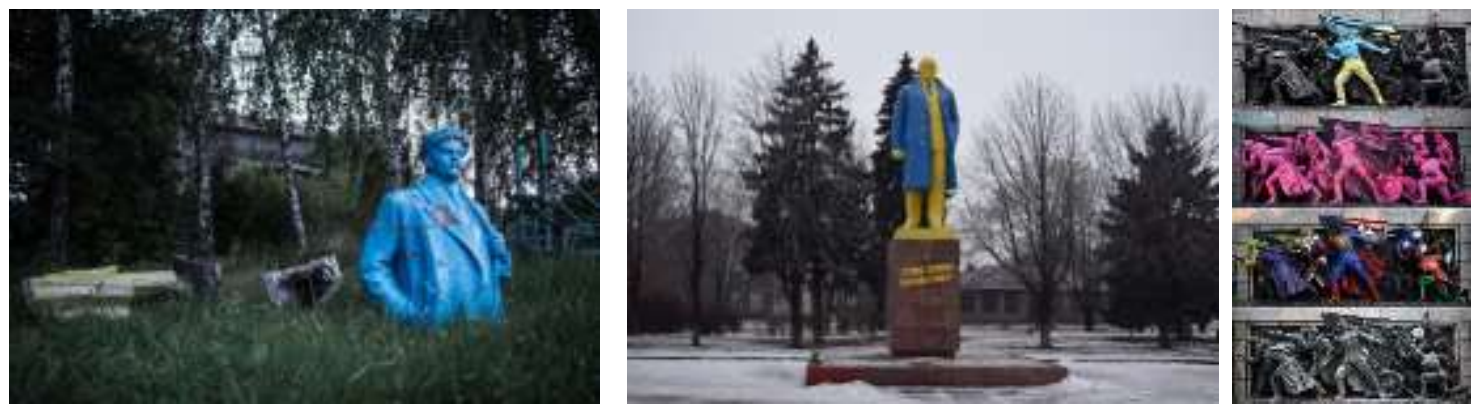

Görsel 3. Hurdalığa terkedilmiş ve Boya ile Müdahale edilmiş Lenin Heykeli, Ukrayna.

Görsel 4. Ukrayna'nın Ulusal Renklerine Boyanmış Lenin Anıtı, Kaidede Ukrayna'ya Zafer-Kahramanlara Zafer Sloganı eklenmiş, Ukrayna.

Görsel 5. Lenin Anıtı'nın Kaidesinde yer alan ve boya ile müdahale edilmiş Sovyet Askerleri Rölyefi. 

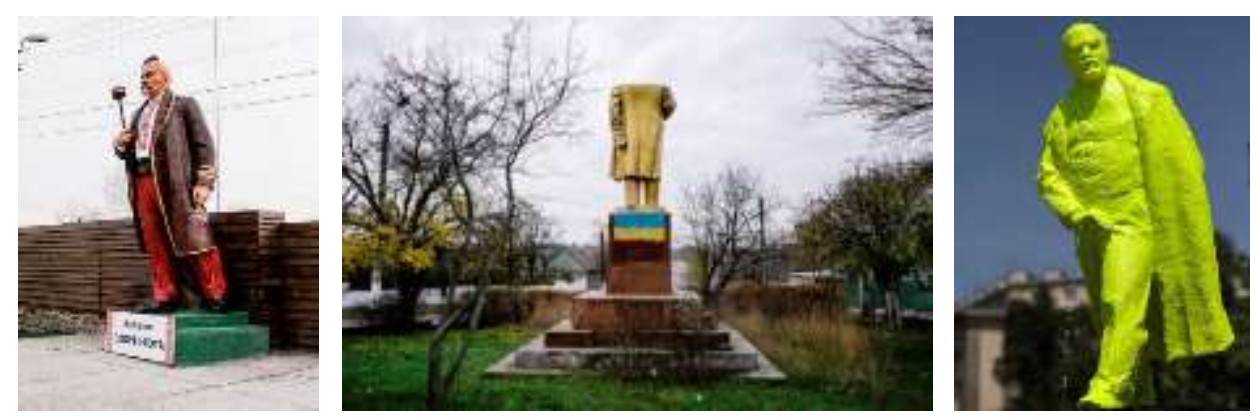

Görsel 6. Boya ile müdahale edilmiş ve plastik eklentiler yapılmış Lenin Anıtı, Ukrayna. Görsel 7. Ukrayna'nın ulusal renklerine boyanmış ve parçalanmış Lenin Anıtı, Ukrayna.

Görsel 8. Krakov, Polonya Grolsch Artboom Festivali'nde idrar yapan Lenin heykeli.

\section{Riga Lenin Anıtı'nın Danimarka'ya Gelişi}

Stalin, Lenin imgesini ölümünün ardından propagandalarında sıkça kullanmış, şehrin bazı caddelerine onun adını vermiş, neredeyse tüm köy, kasaba meydanlarına ve tüm resmî kurumlara Lenin Anıtları yerleştirmiştir (Thompsen ve Gershkovich 1987:51-64). Bahsi geçen heykeller zamanla, Lenin'in organize ettiği yeni toplum oluşturma çabalarındaki sade samimiyetin aksine devasa, yaratılan toplumu aşağıda bırakıp onlara tepeden bakan ve şahsı yüceltmeyi abartı derecesinde vurgulayan anıtlara dönüşmüştür. İstisnasız tüm caddelerde, sokaklarda, okullarda, meydanlarda, parklarda ve resmi binalarda Lenin anıtları dikilmiştir. Okullarda da Lenin imgesi her şekilde eğitimin temel unsuru olarak yeni toplumun en küçük bireylerine dikte edilmiştir (Kelly, 2004:102-122).

Bu anıtlardan bir tanesi Otto Kalêjs 'in (1920-1977) eseridir (Görsel 9). Anıt ilk olarak 1974 yılında Letonya'da Jelgava/Riga'ya yerleştirilmiştir. Sovyetler birliğinin dağılması ile birlikte 1990 yılında Lenin'e adanan heykel, yerel yönetim tarafından bulunduğu meydandan sökülerek depoya kaldırılmıştır. 


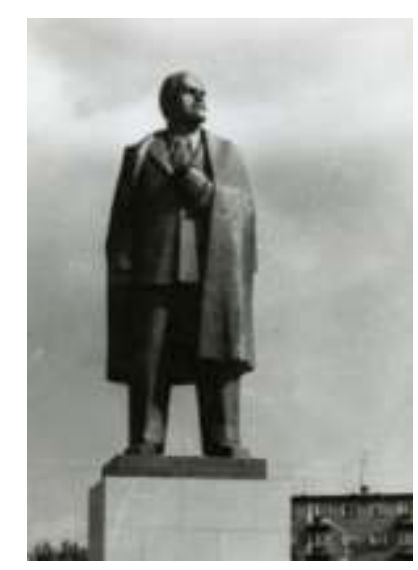

Görsel 9. Otto Kalêjs (1920-1977), Lenin Anıtı, 1974, 10m, Bronz, Letonya Jelgava/ Riga.

Danimarkalı iş adamı, Aage Damgaard Berlin Duvarının yıkılmasını ve hemen ardından Doğu Avrupa'da ki Sovyet anıtlarının yıkıldığını televizyonda izlerken kaldırılmış olan Lenin heykelini görmüş ve koleksiyonunda yer almasının enteresan olacağı kararına varmıştır (Aaes, 2000:1).

Anıtın yalnızca politik bir unsur olmadığı, sanat eseri de olduğu fikrinde olan Aage Damgaard'ın isteği ile oğulları Lars Damgaard ve Søren Damgaard'ın çabaları sayesinde, 1994 yılında babalarının ölümünden üç yıl sonra satın alınarak Danimarka'ya getirilebilmiştir. Aile, Aage Damgaard'ın hayatta olmayışından da kaynaklı, vasiyet niteliği taşıyan heykelin getirildiği ilk birkaç yıl boyunca nasıl ve nerede sergileyeceklerine dair bir fikir geliştirememiştir. Tivoli Parkı çevresinde yer alan restoranlarında konumlandırma planı yapılmış fakat ne şekilde olacağı konusunda başarılı olamamışlardır (Gaidamoviča, 2014:1).

Heykelin üzerinde proje üretmesi için aileye yakınlığı ile tanınan Danimarkalı ressam, heykeltıraş ve Dadaist şair Sven Dalsgaard (1914-1999) görevlendirilmiştir. Satın alınan heykel ilk önce Aage Damgaard'a ait tekstil fabrikasına getirilmiştir. 10 metre yüksekliğinde ve 8 ton ağırlığındaki heykel daha sonra Sven Dalsgaard'a verilen yetki ile yeniden düzenlenmiştir. Sanatçının tasarladığı yeni form/kaide üzerine, Herning şehri Lund kasabasındaki çiftlik bahçesine yerleştirilmiştir. Heykelin orijinalliğine hiçbir müdahale yapılmamış, söküldüğü hali ile Sven'in tasarladığı çatalı andıran dört metre yüksekliğinde iki çelik formun üzerinde yatay yerleştirilmiştir (Görsel 10,11,12).

Sanatçı, heykeli bir kompozisyonun malzemesi/parçası olarak ele almış ve sonuca 
vardırmıştır. Lenin'e adanmış olan anıtın dönüştürülmüş haline de "Lenin er dod" (Lenin Died) ismini vermiştir (Zakharov, 2018:1).

Sven' in heykel teşhirini kurgularken ki tavrı incelendiğinde, sipariş edilmiş olmasına rağmen kendi üretim dili ve açığa çıkan çalışmadaki genel etkiye olan hâkimiyeti dikkat çekicidir. Sanatçının karşılaşabileceği işveren taleplerinin karşısındaki artistik tercih bakımından sınırlılık olasılığından uzak özgür/özgün bir ifade tarzı gözlenmektedir. Abne Samlinger, Dalsgaard'ın çalışmayla ilgili tavrını "Dalsgaard, kendi hayatını sanatsal sürecin temeli olarak kullanmış, tüm üretimini samimiyet ve soyutlama arasında bir kutuplaşma olarak görmüştür. Sübjektif ve evrensel insan, yakın ve mesafeli bakış, gerçek ve hayali arasındaki çift bakış ile- diyalektik, aktif bir sanatçı olarak altmış yıl boyunca tüm malzemelerle ifade biçimleri gerçekleştirmiştir" şeklinde açıklamaktadır (Samlinger,2014).

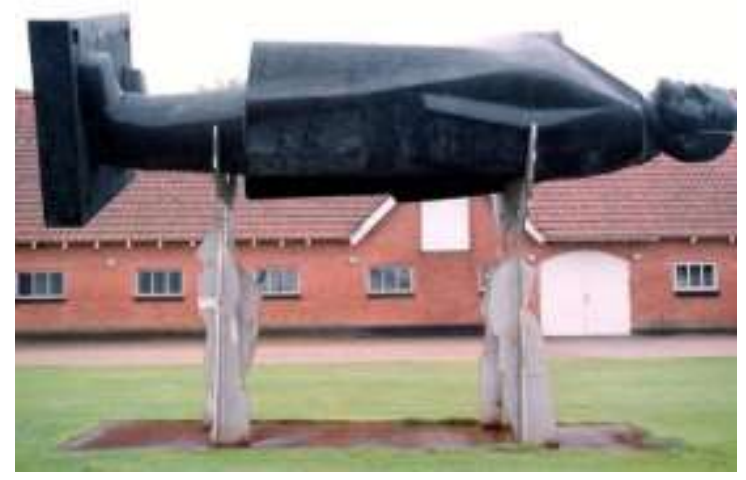

Görsel 10. Sven Dalsgaard, Lenin Died (Lenin Er Dod), 2000, Bronz-paslanmaz çelik, 10x4 m, A Hereford Beefstouw, Danimarka.
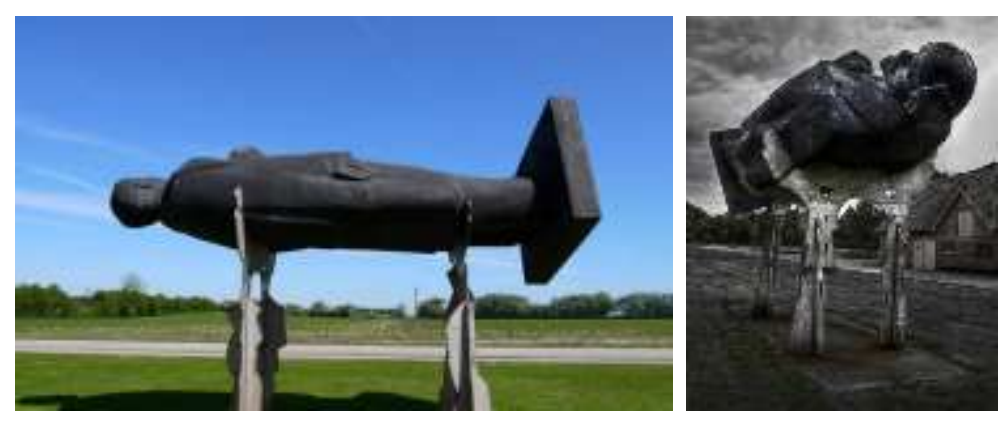

Görsel 11. Lenin Died (Lenin Er Dod), Farklı Açılardan Görüntü.

Görsel 12. Lenin Died (Lenin Er Dod) , Farklı Açılardan Görüntü. 


\section{SDÜ ART-E}

Güzel Sanatlar Fakültesi Sanat Dergisi

Haziran'20 Cilt:13 Sayı:25

ISSN 1308-2698

\section{Anıtın Yeni Kompozisyonu ve Politik Diktesinin Dönüşümü}

Lenin Died heykeli, yeni kurgusunda bütüncül biçimde dönüştürülmüş bir artistik yalınlığa ve olgunluğa sahiptir. Kompoze edilirken kullanılan ve anıtın üzerinde durduğu kaide görevi de gören iki formun plastik etkisi, bilinçli bir şekilde figüratif heykelde kullanılan form etkisinin önüne geçmeyecek şekilde kurgulanmıştır. İki ayrı sanatçının iki ayrı plastik tavrının aynı işte buluşması büyük bir ustalıkla dengelenmiştir. Büyük dönüşüm çok küçük hareketlerle gerçekleştirilmiştir. Heykelin yapılışında öncelikle amaçlanan artistik tavırdan daha önemli görülen işlevsel dikte görevi, farklı bir boyuta taşındığı gibi bir de artistik yeni bir bütüne dönüştürülmüştür. Anıtın (monument) yeni kompozisyonu ile tam tersine çevrilmiş olan politik iletisindeki yeni dil postmodern bir tarifi işaret etmektedir.

Postmodernizm bildik imgeleri yeniden birleştirmek, ödünç alıp kendine uyarlamak ve yeniden ortaya koymak suretiyle o işaret sistemlerinin kışkırtıcı, genellikle eleştirel bakışı sergiler... Temellük (kendine mal etme) bildik imgelerin özgün anlamlarını değiştirmek veya altüst etmek üzere onları yeni bir bağlamda tekrar ortaya koyma yöntemidir (Fortenberry, 2015:28).

Lenin Died, kitsch bir etkiden uzak yeni tarifiyle eskiyi tartışarak cevap veren yeni bir anıt olarak değerlendirilebilir. Artık bir sistemi, politik görüşü veya bir lideri anlatmayan yalnızca hikâyesini tarihten alan artistik amacı daha ön planda bir esere dönüşmüştür.

Anıt heykeller, sistemin diktesini sürekli kılması amacına vekâlet eden nesnelerdir. Lenin anıtı bir iktidarın söylediklerini meydanlarda tekrarlarken şimdi başka bir yerde yeni bir kurgu ile başka bir fikri hatta eskiye muhalif olarak dikte etmeye devam etmektedir. Anıt heykelin değişmez vazifesini ya da kaderi olan anma/övme/dikte etme görevini her ne olursa olsun kılık değiştirerek sürdürmektedir. Heykel (Lenin Died) artık ezici dikey yüksekliği ile sert ve ezici anıtsal etkisini yitirmiş, yatay kullanımı ile de bir hikâyenin anısına adanan heykele dönüştürülmüştür. Günümüz kamusal alan heykellerinde kullanılan insana yakın, sosyal yaşam sürecinde varlığının nedeni olan izleyicisinin ebatlarına uygun olarak tasarlandığından sakin bir etkiye kavuşturularak sivilleşmiştir. Daha önceki resmi aidiyetinden farklı olarak özel bir mülkiyete dönüşmesi ve ardından açık alanda arz edilmesi ile asıl şimdi kamuya mal olmuştur. Geçmişi unutmaması gerekenin de zaten kamunun olması gerektiği düşünüldüğünde, bir anıyı canlı tutan heykele evrilmesi ile sonuca ulaşmış ve bu yolla da başarılı bir şekilde yerel kimliğinden kurtularak 
evrenselleşmiştir. Lenin'e adanmış bir Sovyet anıtından kopmuş Danimarka'da konumlandırılmış sanat eseri niteliği ile varlık gösteren ve bir heykele dönüşmüştür. Artık iktidarın propagandası için kullanılarak kamusallaşan anıt, sistemin düşüşü veya bağlamından koparılışı ile gerçek anlamda kamuya arz edilmiş ve tüm insanlığa dair evrensel bir ifade kazanmıştır.

Lenin anıının farklı bir üretimin parçası amaçlı kullanımı, heykelin enstalâsyonda kullanılan hazır nesne olarak adlandırılması şeklinde de düşünülebilir. Bahsi geçen heykel figüratif üslubuna rağmen, yeni tarifi ile soyut bir kompozisyonun figüratif bir modülü halinde varlık bulması yeni artistik sorgulamalar yaratmaktadır. Heykelin 1980 sonrasına tekabül eden postmodern tavırla dekoratif bir nesnenin ötesine geçmesi ve bir anıtın nesnel vazifesinden öte sosyal içeriğinin tartışıldığı bir buluşma şeklinde tarif edilebilir.

Yeni heykelin bütünü artık ne figüratif ne de soyuttur. Lenin Died, Sven Dalsgaard'ın kendi plastik diliyle, bulunan bir hazır nesnenin yeni düzenlemesiyle yapılan bir önermedir. Her şekilde heykelin genelinde bir düalite söz konusudur. İki sanatçının katkısıyla bugün buradadır, dünü anlatır ve yarına dair de söyleyecekleri vardır.

Hazır nesne kullanımında sıradan günlük yaşam nesnelerinin kimlikleri, dönüştürülmek adına silinmeye çalışıır ya da sonuçta amacının dışına çıkan nesne yeni bir şey haline gelir. Anıttaki Lenin imgesinin değişmemiş (tahrip/tahrifata uğramamış) olması ile anıtsallık özelliğinin devam ettiği söylenebilir fakat kompoze edilerek gerçekleştirilen dönüştürme işlemi ile tersten bir dikte yaratılmış olması düşünüldüğünde metamorfoz (başkalaşma) başarılı olmuştur.

Yeni heykelde, yaşayanı temsil eden dik duruş artık ölümü ve bitmişliği temsil eden yatar pozisyonla dönüştürülmüştür. Eski Lenin anıtının nesne olarak kimliği silinmemiş dönüşüm iki farklı plastik tavrın dengede tutulması ile nötrleştirilmiştir. Bu tavır, tarifte bulunmaya çalışacak olan alımlayan özneyi iki farklı üsluba karşı tarafsız kılmakta ve açığa çıkan ikili kompozisyonu aslında bütün algılaması gerekliliğine ikna etmektedir. Ayrı ayrı sergilendiğinde dahi tek başlarına farklı şeyler tarif eden (farklı plastik olgunluğa sahip) iki heykelin amalgam hali sayesinde, anıtın eski eziciliğinin tersine bütünde yeni ve farklı bir eklektik ifadeye ulaşılmıştır.

Otto Kalejs'e ait Lenin Heykeli, inşa edildiği dönemin özelliklerini taşımaktadır. Neredeyse geometrik bir çözümleme ile sert ve ezici formların hâkim olduğu, iktidarın ve diktelerinin 
mutlakıyetini vurgulayan bir form etkisi gözlemlenmektedir. Üretildiği yılarda Rusya'nın genelinde görülen sanat ortamının (soyut sanatın tartışıldığı) geride bıraktığı bir plastik dile sahip olan figüratif propaganda heykellerinin neredeyse tamamında aynı keskin hatlar izlenmektedir. Buna karşın Sven Dalsgaard'a ait kaide vazifesi de gören diğer heykelde (plastik kısımda), üstteki figüre uygun dekupe edilmiş yumuşak soyut formlar mevcuttur. Üstündeki figür olmadan düşünüldüğünde Sven'e ait kısım suskun, alttaki kısım olmadan Lenin Anıtı ise kimliği gereği çok mesaj ileten ezici bir etkiye sahiptir. Dengeyi sağlayan unsur Sven'e ait kısmın organik yalınlığı ve biçimle bir şeyi iletmeyişidir ya da ileti derdinin olmayışıdır. Bahsi geçen çelik formlar üzerine Lenin heykeli konulduğunda, bakışın/cephenin gökyüzüne yöneltilişi ile kendiliğinden açığa çıkan bir dikteye hizmet eden yeni bütünün bir parçası haline gelmiştir.

"Lenin Lived, Lenin Lives, Lenin Will Always Live" (Varoli, 1997) söylemleri ile var edilmiş olan Leninizm'i öven anıtlardan birisi olan bu heykele, Sven Dalsgaard tarafından Lenin Died adının konulması dikkat çekicidir. Anıtın bir hazır nesne olarak kullanıldığı düzenlemenin etrafındaki modüler parçalar Lenin'i ayakta tutan Sven'e ait metal parçaların devamı niteliğindedir (Görsel13). Bütün alandaki (sergilendiği mekân) kompozisyon satranç tahtasını andıran iki piyon ve devrilmiş/ mat olmuş bir erki temsil eder. Heykelin yatırılması, önceki anıt kimliğini işlevsiz kılmıştır ve gökyüzüne dikey yükselişi ile hâkimiyet kurduğu ezici algısal gücünü artık yitirmiştir.

"Lenin daima havada yatmak zorunda, onların istediği gibi uzanıyor. Tüm dünyadaki gelişmeler adına sonunda iflas eden güçlü bir insanın sembolü olarak önemli bir biçim... Birisi bana, şimdi orada onun yatarken demokrasinin nasıl işlediğini seyrettiğini söyledi"...diyor Bitten Damgaard (Aaes, 2000:1).

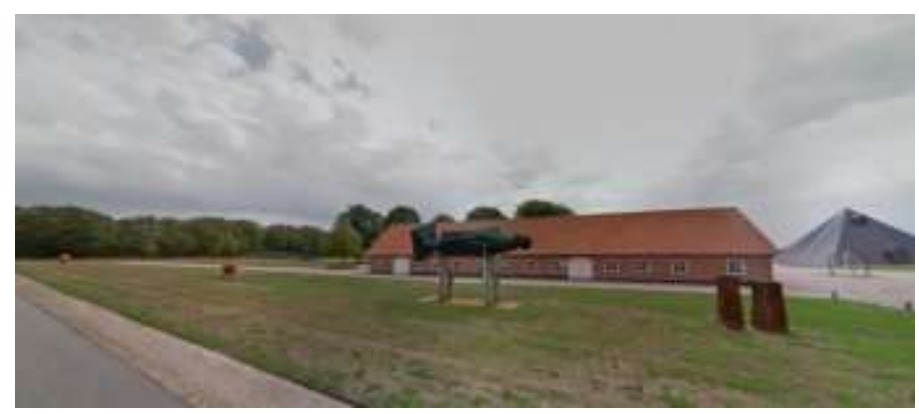


Görsel 13. Lenin Died Heykeli'nin Konumlandırıldığı Alan.

Lenin'in yeni pozu artık yeryüzüne dair bir yönü vektörel olarak tarif etmemektedir. Anıt heykelde etkiyi yükselten bir unsur olarak kullanılan bakışın ve bedensel yönelişin, ideolojinin bir zamanlar hâkim olduğu nesnel yeryüzünden boşluğa, sonsuzluğa yani gökyüzüne yöneltilmesi ile de muhafazakâr/ikonolojik bir okumayla tanrı ile hesaplaşması gerekliliği olarak yorumlanabilir.

Sanatçının, anıtın dönemindeki plastik dile karşı kendi kurgusunda modern biçimler kullanışı, iki parça arasında eklektik bir farklılığı açığa çıkarırken eski bir sisteme vekâlet eden eski biçim dilini sanatçının modern formları ayakta tutmaktadır. Lenin, artık hatırlanması gerekli olsa bile bunu dikte edecek olan heykeli, ironik olarak mevcut kendi kaidesi ile birlikte modernizmin kucağında Sven'in mozoleyi andıran soyut formları üzerinde varlığını sürdürmektedir. Heykelin bütününde nostaljik bir yenilik söz konusudur. Bahsi geçen nostalji,

ille de reel sosyalizme yahut Stalinizmin enkaz olmuş diğer biçimlerine duyulan nostalji demek değildir. Kaybedilen nesne bir rejim ya da ideolojidense, bütün kırılganlı̆̆ına, istikrarsızlığına ve geçiciliğine rağmen hatırlanmaya değer tarihsel bir deneyim mahiyetindeki bir özgürleşme mücadelesi de olabilir. Bu açıdan, geçmiş intimallerin anısı ve farkındalığı demektir melankoli; devrimin neticelerine değil, özgürlükçü vaatlerine duyulan sadakattir. Bu durumda melankoli, Slavoj Zizek'in konuya ilişkin dediği gibi, bir kayıptan ziyade, eksiklik ile özdeşleşmedir. Komünizmde gerçekleştiği haliyle değil (devlet sosyalizmi), hayal edildiği ve beklenildiği haliyle özdeşleşmedir. Bu tür bir sadakat, geçmişi işlemeye yönelik her türlü çabanın özüdür (Traverso, 2018:89).

Heykelin yol kenarında yerleştirilmesiyle, bölgenin tarımsal üretim merkezi olması gerçeği ile de gelip geçen çiftçilere dekoratif ve fetişleştirilmiş tarihsel bir anı nesnesi gibi teşhir edilmiştir. Artık kendi gölgesi üzerinde yatan ve yalnızca boşluğa hâkim bir pozisyonda teşhire sunulmuştur. Ayakta kurgulanmış olan figüratif heykelin yatay bir şekilde kompoze edilmesi ile algısı alt üst olan izleyenin üzerinde şok etkisi yaratmaktadır. Bu etki, anıtların ortak kaderi olan ve gelip geçerken alışıldığından/sıradanlaştığından dolayı açığa çıkan psikolojik körlükten kurtarıp süjeyi mevzu üzerinde düşünmeye davet etmektedir, hatta alıkoymaktadır. Yol kenarında yerleştirilmiş olan heykelin önünden geçilirken tecrübe edilen süreç ile şu an etkisini yitirmiş olan sistemin bellekte kalan kötü anıların geride bırakılarak silinmesi fikrini uyandırmak da alegorik bir hedeftir.

Lenin anıtının Letonya'daki meydandan kaldııldıktan sonra Aage Damgaard'ın çocukları 


\section{SDÜ ART-E}

Güzel Sanatlar Fakültesi Sanat Dergisi

tarafından Danimarka ya getirilmesi ve 1995 yılında bahçeye konulması, kendiliğinden açığa çıkmış (bir anıt kimliğinin geçersiz kılınması) ironik bir durumdur. Daha sonrasında Sven Dalsgaard tarafından yeniden kompoze edilişi ve çiftliğin yol cephesinde sergilenişi ise bilinçli bir kurgu söz konusu olduğundan yarattığı alt okumalar sebebiyle sarkastik bir tavırdır.

Yaratılmış ironi, belirli bir fikri veya hissi dil ile ifade etmek yerine, Lenin'i bağlamından kopararak dekoratifleştirmiş, yine artistik bir kod ile uluslararası bir ifade açığa çıkarılmıştır. Şehirde geleneksel olarak düzenlenen festivallerde (Smukfest) teşhir amaçlı geçici olarak taşınmasıyla hem yeni dikte ediş hali hem de dekoratif nesnelliği vurgulanmaktadır (Soren, 2017). Dekoratif olan, bir şeye hizmet eder ve kaldırıldığında ya da yeri değiştirildiğinde enflasyonik kimliğini de tekrar varlık bulmak üzere yeni yerine taşımaktadır (Görsel 14,15).
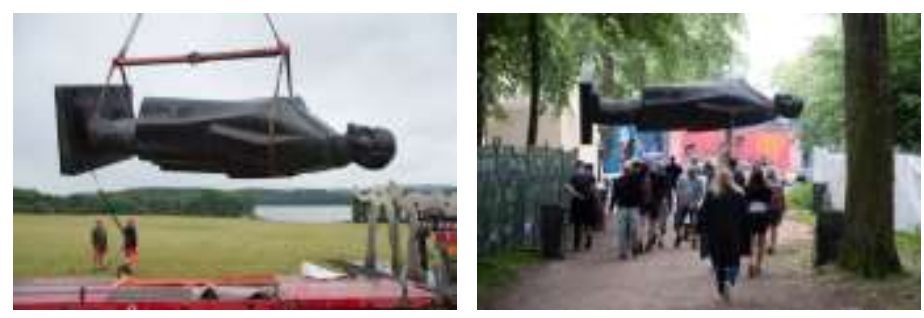

Görsel 14. Smukfest Festival Alanına 'Aşk' kampına taşınan Lenin Died Heykeli. Görsel 15. Smukfest Festival Alanı'nda Lenin Died Heykeli, 2017.

Sırtüstü yatan heykelin bu okumasının yanında, Lenin heykelinin yeni pozisyonu ile Kızıl Meydan'daki Lenin'in mozolesi ikonolojik açıdan benzerlik göstermektedir. Sven Dalsgaard'ın kompoze edişiyle tekrar kamusal alanda boy gösteren heykeldeki yatay Lenin; devrilmeyi, ölümü, sonsuz uykuyu ve bir sonu anlatır. Kızıl meydandaki mumyalanmış bedeni ile benzer şekilde levhalar üzerinde sırt üstü yatırılmış Lenin temsili arasında algısal bir bağ kurulabilir.

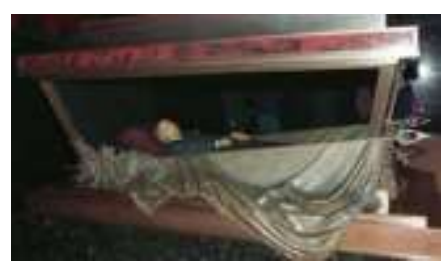

Görsel 16. Kızıl Meydan'da yer alan Lenin Mozolesi, Moskova-Rusya. 

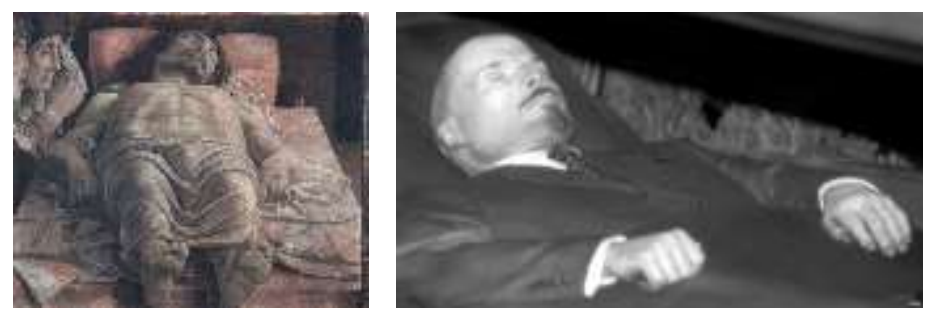

Görsel 17. Andrea Mantegna (1431-1506), Ölü İsa'ya Ağıt (Lamentation Over The Dead Christ),1480, Tuval üzerine tempera, Pinacoteca di Brera, Milan.

Görsel 18. Lenin Mozolesi (Detay).

Stalin sayesinde yaratılmış olan neredeyse Mesih haline dönüştürülmüş Lenin imgesi ister Kızıl Meydan'daki mozolede ister Danimarka'nın Lund Kasabası'ndaki çiftlik bahçesinde yer alan heykelin kompozisyonunda olsun, çarmıhtan indirilmiş İsa imgesiyle de örtüşmektedir (Görsel16,17,18). Hristiyan inancındaki İsa'nın bedeninin çürümediği gibi Stalin'e göre ne bronz ne de komünist beden çürümeyecektir.

"24 Ocak 1924 tarihinde Stalin İkinci Sovyetler Kongresinde bir yas konuşması yaparak Lenin'in mirasını gerçekleştirme ve proletarya diktatörlüğünü sağlamlaştırma sözü verdi. Sözlerine şöyle başladı: Biz komünistler özel kumaşı olan insanlarız. Bizler özel malzemeden yapılmışız. Komünist beden çürümez" (Buck-Morss, 2004:85).

Kızıl Meydan'daki amaç ile Lund kasabasındaki amaç Lenin'in unutulmaması adına benzerlik taşısa da diktelerdeki hedeflenenler farklıdır. Stalin'in Lenin'i ölümsüz kılma çabasının tam tersini vurgulayan bir ifade yaratılmıştır. Şu an dikte edilen Lenin'in ve ideallerinin ölümü hatta bu ölümü de içine alan komünizmin başından günümüze serüveni yani ölümünden sonrasıdır. "geçmişle ilgili bilgi edinme girişimi aynı zamanda ölünün dünyasına yolculuktur" (Kerrigan, 2018:7).

Heykel artık Sovyet iktidarının kaybetme korkusundan kaynaklı kaygılarının sona ermesi gerektiğini ima etmektedir. "Lenin Died" da kullanılan Lenin de komünizm ideali de ölmüştür ve ölüler kaygılanamaz.

"Pruşevski! Bilim cesedi çürüyen insanları diriltmeye muktedir mi? "Hayır" dedi Pruşevski. Zaçev gözlerini açmadan "Yalan Söylüyorsun" diye suçladı onu. Marksizm her şeyi yapabilir. O zaman nasıl oluyor da Lenin Moskova'da bozulmadan yatabiliyor? Bilimi bekliyor-diriltilmek istiyor."(Buck-Morss, 2004:91). 


\section{Sonuç}

Erki dikte eden anıt heykeller boyutları ile ezici ve kodlarla donatılıılarından hikâyecidir. Tarihsel bir anıya adanan heykeller ya da farklı uygulamalar ise üzerinde durulan meselenin hafızalarda sürekliliği hedefleyen uygulamalardır ve genellikle alımlayanın hikâyeyi anlaması adına bir plaket (kitabe) barındırır. Anıtsal heykellerden farklı, bu küçük boyutlu bir kitabe olabileceği gibi kitabesi olan temsili bir form veya mimari bir unsur da olabilir. Kamuya ait olan anıların canlı kalmasını sağlar. Otto Kalejs'in Lenin anıtı ile Sven Dalsgaard'ın Lenin Died heykeli, Türkçenin "monument" ve "memorial" kavramlarını açıklamaktaki yetersizliğine cevap veren ve alan terminolojisinin gelişimi adına örnek teşkil edebilecek bir çalışmadır.

Lenin Died, günümüzde hala günceliğini korumakta olan kamusallık tartışmalarına da farklı cevap verir nitelikte bir uygulamaya dönüşmüştür. Bahsi geçen tartışmaların alandaki yansıması olan kamusal heykellerin resmî kurumları temsilinin dışında sivil bir kimlik ile de halka açık alanlarda var olabileceğini vurgulayan uygulamalardan biridir. Üstelik bu örnekte bir iktidar temsili sivil bir girişim için malzeme olarak kullanılmıştır.

Bu heykel Lenin'in yanı sıra komünizm kalıntılarının da yeniden kurgulanmasıdır. Yapılan müdahalede biçim bozma yerine konvansiyonel anıt tarifinin ötesine geçilmiştir ve yoğun bir ironi tercih edilmiştir. Geçmişte komünizmin ve onu yücelterek yaygınlaşmasını/kalıcılığını hedefleyen sembollerinin açığa çıkardığı belleği tersine dönüştürmek amaçlı Lenin heykeli dekoratif bir unsur olarak sunulmuş, yeniden yorumlanmıştır. Bir sanatçının formunun, başka bir sanatçının formunu, yeninin eskiyi, başlayanın bitmişi, bugünün dünü ayakta tutan çatal biçimler "montür" görevi gören yeni bir teşhir nesnesi olarak tasarlanmıştır. Her devirde Leninlerin olabileceğine dair alt okumalar içeren yeni düzenleme, postmodern bir tavırla tekrarların daimiliğini işaret eden bir derse/sonuca dair salık vermektedir. Yeni yaratılan biçimde tekrar açığa çıkan farklı anıtsallığının altında yatan yeni dikte bu şekilde yorumlanabilir.

Heykelin yeni oluşumun bir parçası olarak tekrardan kurgulanmış yeni politik söylemi ise Lenin'in başlangıçta kullandığı ajitatif propagandanın yani hayatın tiyatrolaştırılması ile de bütünlük kazanmıştır. Eski bir hayatın, idealin ve erkin bugün canlandırılmasında dekor olarak kullanılmıştır. Bir heykelin hikâyeden uzak durarak yalnızca kurgu (biçimsel) ile söylem 


\section{SDÜ ART-E}

Güzel Sanatlar Fakültesi Sanat Dergisi

yaratmasına, İroni ve sarkazm kavramlarının plastik sanatlardaki tarifini karşılaması adına iyi bir örneklemdir.

Lenin anıtının geçmişteki yeni toplum düzenine dair olan politik ileti görevi sona ermiştir. Heykelin başka bir sanatçı tarafından dengeli bir müdahale ile eski kimliğine zarar verilmeden konservasyonu sağlanarak yorumlanmıştır. Bu yorumlayış tarihsel ve plastik tavır bakımından da bir eski-yeni hesaplaşması yaratmıştır. Tarihe bağımlı üst kısmı figüratif ve ona destek alt kısım ise güncele aittir. Yeni kurgulama sürecinde yapılan müdahalelerde, o dönem dağılan eski Sovyet ülkelerindeki tavırdan farklı olarak hakaret içermeyen ve aşağılamaya müsaade etmeyen bir tavır gözlemlenmektedir.

Lenin de O'nun ideal toplum düzeni de ölmüştür. Fakat iletinin devam etmesini sağlayan fiziksel varlığı korunduğundan sonsuzluğa erişen Lenin imgesi, "Lenin Died" heykelinde farklı bir söyleme dönüştürülürken geçmişi hayatta/akılda tutmayı da başarmaktadır.

Kendi zamanı içinde Lenin heykeli minnettarlık, teşekkür ve bunun sonsuzlukla ödüllendirilmesini imlemiştir. Oysa bugün Lenin Died heykeli o anlamın dışına taşmıştır. Postmodern dünyanın, tarih olgusuna, nostalji yoluyla saldırmanın somut göstergesidir. Lenin artık yatay/devrik pozisyondadır ve sanatçı tarihle seviyeli bir üslupla dalga geçmiştir.

\section{Kaynakça}

Buck-Morss, S. (2004). Rüya Âlemi ve Felaket, çev. Tuncay Birkan, İstanbul: Metis Yayınları.

Clark, T. (2017). Sanat ve Propaganda, çev. Esin Hoşsucu, İstanbul: Ayrıntı Yayınları, s:94-108.

Fortenberry, D. (2015). Art in Time/A World History of Arts and Movements, London: Phaidon Press Limited.

Goldman, E. (2008). Rus Devriminin Çöküş Nedenleri, çev. Yakup Coşar, Ankara: Dipnot Yayınları.

Kelly. C. (2004). "The Leader Cult in Communist Dictatorships". The Functions of the Leader Cult: Grandpa Lenin and Uncle Stalin: Soviet Leader Cult for Little Children, ed. Balázs AporJan C. BehrendsPolly JonesE. A. Rees, London: Palgrave Macmillan, s.102-122.

Kerrigan, M. (2018). Ölümün Tarihi, çev. Sibel Erduman, İstanbul Paris Yayınları.

Thompsen, O. H. , Gershkovich, A. (1987). "Russia's Official Religion”, Profesors World Peace Academy, International Journal on World Peace, Vol. IV, Oct-Dec1987, 4, s.51-64. 
Traverso, E. (2018). Solun Melankolisi, çev. Elif Ersavcı, İstanbul: İletişim Yayıncılık.

\section{İnternet Kaynakları}

Aaes, J. (2000). "Lenins Midtjyske Lit De Parade" Jyllands- Posten Indland, 24 Mart, s.1. https://jyllands-posten.dk/indland/ECE3284106/Lenins-midtjyske-lit-de-parade/, Erişim tarihi:12.11.2018.

Gaidamoviča, R. (2014). “Muzejnieki Dānijā «satiek» Jelgavas L̦eṇinu” Jelgavas Vestnesis, 03 Temmuz, s.1. http://www.jelgavasvestnesis.lv/kultura/muzejnieki-danija-satiek-jelgavas-leninu, Erişim tarihi: 13.12.2018.

Lilmoes, S. P. (2017), TV2 Østjylland, "Smukfest Rejser Ttatue af Diktator Ved Motorvej". https://www.tv2ostjylland.dk/artikel/smukfest-rejser-statue-af-diktator-ved-motorvej, Erişim tarihi: 22.09.2018.

Samlinger, A. (2014). Fuglsang Kunstmuseum "Sven Dalsgaard 100 AR", http://www.aabnesamlinger.dk/fuglsangkunstmuseum/udstillinger/tidligere-udstillinger/sven-dalsgaard-2014/, Erişim tarihi: 06.07.2018.

Wollan, M. (2017), The New York Times Magazine, "How to Pull Down a Statue" , https://www.nytimes.com/2017/09/15/magazine/how-to-pull-down-a-statue.html,17 September p.32, Erişim tarihi: 11.04.2019.

Varoli, J. (1997), Radio Free Europe/Radio Liberty, "Russia: Lenin Lived, Lenin Lives, and Lenin Will Always Live", https://www.rferl.org/a/1087158.html, Erişim tarihi: 01.08.2019.

Zakharov, A. (2018). "Lenin was killed: in Denmark showed the right decommunization", Vgorode. UA, 31 Ekim, s.1. https://kiev.vgorode.ua/news/sobytyia/378296-v-danyy-pokazalypravylnuui-dekommunyzatsyui, Erişim tarihi: 29.05.2019.

\section{Görsel Kaynaklar}

Görsel 1. "Kiev'deki Bessarabska Meydanı'ndaki Lenin Anıtının Yerine Önerilen Proje". https://www.nytimes.com/2017/09/15/magazine/how-to-pull-down-a-statue.html, Erişim tarihi: 22.06.2019.

Görsel 2. Yuri Gerasimov, "Lenin", 1990, Bronz, Red Square Apartmanı çatısı, Amerika. https://www.6sqft.com/why-does-this-east-village-building-have-a-statue-of-vladimir-lenin-ontop/, Erişim tarihi: 03.09.2019.

Görsel 3. Hurdalığa terkedilmiş ve Boya ile Müdahale edilmiş "Lenin Heykeli”, Ukrayna. https://www.vice.com/en_ca/article/nejpwx/decapitating-lenin-statues-is-the-hottest-newtrend-in-ukraine, Erişim tarihi: 22.01.2019. 
Görsel 4. Ukrayna'nın Ulusal Renklerine Boyanmış “Lenin Anıtı”, Kaidede Ukrayna'ya ZaferKahramanlara Zafer Sloganı eklenmiş, Ukrayna.

https://www.reddit.com/r/pics/comments/2u2v7s/a_statue_of_lenin_gets_an_interesting_pai ntjob_in/, Erişim tarihi: 12.09.2018.

Görsel 5. "Lenin Anıtı' nın Kaidesinde yer alan ve boya ile müdahale edilmiş Sovyet Askerleri Rölyefi". https://444.hu/2014/08/21/oroszorszag-megunta-hogy-szofiaban-allandoan-atfestika-szovjet-katonai-emlekmuvet, Erişim tarihi: 22.01.2019.

Görsel 6. Boya ile müdahale edilmiş ve plastik eklentiler yapılmış "Lenin Anıtı", Ukrayna. https://www.artrabbit.com/events/looking-for-lenin, Erişim tarihi: 22.01.2019.

Görsel 7. Ukrayna'nın ulusal renklerine boyanmış ve parçalanmış "Lenin Anıtı", Ukrayna. https://www.vice.com/en_ca/article/nejpwx/decapitating-lenin-statues-is-the-hottest-newtrend-in-ukraine, Erişim tarihi: 20.11.2019.

Görsel 8. Krakov, Polonya Grolsch Artboom Festivali'nde "idrar yapan Lenin heykeli". https://www.independent.co.uk/news/world/europe/polish-town-erects-fluorescent-statueof-lenin-urinating-called-fountain-of-the-future-9534076.html, Erişim tarihi: 22.01.2019.

Görsel 9. Otto Kalêjs (1920-1977), "Lenin Anıtı", 1974, 10m, Bronz, Letonya Jelgava/ Riga. http://leninstatues.ru/photo/6246/herning, Erişim tarihi: 12.03.2019.

Görsel 10. Sven Dalsgaard, "Lenin Died (Lenin Er Dod)", 2000, Bronz-paslanmaz çelik, 10x4 m, A Hereford Beefstouw, Danimarka. https://jauns.Iv/raksts/zinas/259962-savdabigs-liktenispiemeklejis-jelgavas-leninekli Erişim tarihi: 07.04.2019.

Görsel 11. "Lenin Died (Lenin Er Dod)", Farklı Açılardan Görüntü. https://starcom68.livejournal.com/1609595.html Erişim tarihi:18.05.2019.

Görsel 12. "Lenin Died (Lenin Er Dod)", Farklı Açılardan Görüntü. https://jyllands-posten.dk/livsstil/rejser/danmark/ECE8752005/lenin-paa-langs/ (Fotoğraf: ARNE RUDI JENSEN 2016), Erişim tarihi: 11.04.2019.

Görsel 13. “Lenin Died” Heykeli’nin Konumlandırıldığı Alan. https://virtualglobetrotting.com/map/the-lenin-statue-in-the-danish-village-oflund/view/google/, Erişim tarihi: 15.18.2019.

Görsel 14. Smukfest Festival Alanına "Aşk kampına taşınan Lenin Died Heykeli". https://stiften.dk/artikel/se-video-d\%C3\%B8d-russisk-diktator-kommer-liggende-til-smukfest2017-6-29\#slide0, Erişim tarihi: 13.12.2018.

Görsel 15. Smukfest Festival Alanı'nda "Lenin Died Heykeli”, 2017. 
https://www.smukfest.dk/nyheder/oplevelser/streetart-paa-skovtur, Erişim tarihi: 15.08.2019.

Görsel 16. Kızıl Meydan'da yer alan "Lenin Mozolesi", Moskova-Rusya. http://www.gezilecekyerler.biz/lenin-mozolesi/, Erişim tarihi: 08.10.2019.

Görsel 17. Andrea Mantegna (1431-1506), “Ölü İsa’ya Ağıt (Lamentation Over The Dead Christ)",1480, Tuval üzerine tempera, Pinacoteca di Brera, Milan.

https://www.arteworld.it/wp-content/uploads/2017/12/Cristo-morto-Andrea-Mantegna.jpg, Erişim tarihi: 17.09.2019.

Görsel 18. "Lenin Mozolesi" (Detay).

https://www.wikisosyalizm.org/images/2/28/Lenin_naa\%C5\%9F.jpg, Erişim tarihi: 13.12.2018. 